\title{
Emerging Adults' Perceptions of Their Father Involvement: Significant to Sociosexuality
}

\author{
Zhillan Zhalyla $^{1}$ \\ ${ }^{1}$ Faculty of Psychology, Universitas Indonesia \\ *E-mail: zzhalyla@gmail.com
}

\begin{abstract}
This study was conducted to examine the correlation between father involvement and sociosexuality among emerging adults. Father involvement defined as the extent to which father's participation in all aspects of a child's life (Finley \& Schwartz, 2004). Meanwhile, sociosexuality defined as individual differences of a willingness to have sex without a commitment (Penke \& Asendopf, 2008). The instruments used in this study are Nurturant Fathering Scale (affective domain) and Father Involvement Scale (behavior domain) developed by Finley and Schwartz (2004) to measure father involvement and Revised Sociosexual Orientation Inventory (Penke \& Asendorpf, 2008) to measure sociosexuality. Respondents of this study were 526 emerging adults (18-25 years old, 145 females \& 381 males). There was a negative and significant relationship between father involvement, both on affective domain or behavioral domain, and sociosexuality on emerging adulthood. Further explanation will be discussed.
\end{abstract}

Keywords: emerging adulthood; father involvement; sociosexuality

\section{Introduction}

Over a few years ago, Arnett (2000) developed the concept of emerging adulthood. Emerging adulthood is the individual developmental transition period from late adolescence to adulthood, with a focus on ages 18-25. In this period, emerging adults have not yet entered the adulthood which has so many normative responsibilities and developmental tasks (Arnett, 2000). Emerging adults are also fulfilled with opportunities for self- exploration of the variety of possibilities in life, especially in terms of love, work, and worldview. In terms of love, emerging adulthood is distinct from adolescence because, in this period, love becomes more intimate and more serious (Arnett, 2000). Commitment tends to develop in this period, so the emerging adults begin to look for a potential future life partner (Arnett, 2013). Love for emerging adults is no longer concerned with pleasure alone but its focus is to explore the potential of physical and emotional intimacy (Arnett, 2000).

Several studies related to physical intimacy in emerging adults in America were conducted by
Michael, Gagnon, Laumann, and Kolata (Arnett, 2000). They found that physical intimacy in emerging adulthood is more likely to involve sexual intercourse. Sexual activity in this period mostly occurred in the context of a romantic relationship. However, Indonesia is a state that still upholds the religious norms and eastern culture and because of that, exploration of sexual experiences becomes one of the taboo issues to discuss. In contrast, lately, there have been many phenomena that show that some people, particularly students (aged 18-25 years) in Indonesia have already had sex, even not only with their romantic partner but also with someone they have not known well.

The rise of prostitution, including online prostitution (Lestari \& Dono, 2016), recently shows that sexual needs can be obtained not only from the partner but also with other people who do not have a close relationship with them. Nowadays, the ease to explore in searching a sex partner can be obtained through various online applications, such as application in the smartphone that allows someone to get acquainted with strangers around them. By doing this, people can easily find a sex partner 
without initially making friends or building a close relationship with them. It is also possible in Indonesia to have a 'one-night stand' partner gained through an online application (Safiera, 2015).

A phenomenon that has been described previously shows that there are people who can fulfill their sexual needs and sexual desires not only with their partner but also with someone who they have no close relationship or commitment with. This is described by the concept of sociosexuality or sociosexual orientation. The concept was first proposed by Kinsey and his associates in 1948 . He described sociosexuality as "the individual differences in people's willingness to engage in uncommitted sexual relationships" (Penke \& Asendorpf, p.1113, 2008). In 1991, Simpson and Gangestad explored the concept of sociosexuality more deeply and for the first time, they successfully developed the sociosexuality inventory. Sociosexuality can be classified into two categories, which are restricted sociosexual orientation and unrestricted sociosexual orientation. Restricted sociosexual orientation is described as a person who needs commitment or intimacy before being involved in sexual activity or sexual relationship (low sociosexuality). Unrestricted sociosexual orientation is described as a person who is willing to involve in sexual activity without commitment or intimacy (high sociosexuality). There are three components of sociosexuality: 1) sociosexual behavior is someone's experiences about their past sexual activity or sexual relationship; 2) sociosexual attitude is someone's evaluative disposition toward uncommitted sex; 3) sociosexual desire is the state when the sexual desire or sexual interest is heightened.

Hall and Pichon (2014) found that sociosexuality was related to the potential occurrence of sexually transmitted infections (STI). People with high sociosexuality tend to involve in sexual activity that can lead to various risks, such as sexually transmitted disease, HIV/AIDS, even pregnancy in women. Several studies have also shown the risks of engaging in sexual activity without commitment, such as less pleasure and warmth compared to romantic sex, often regret, feel an unwanted emotional closeness, drugs abuse, and social stigma (Allison \& Risman, 2013; Cooper, 2002; Filder \& Carey, 2010b in Vrangalova \& Ong, 2014).

Based on cases in Indonesia about sociosexuality in emerging adulthood, it can be assumed that there is a discrepancy between the ideal and the actual condition. The actual condition shows that nowadays there were emerging adults in Indonesia who were willing to engage in sexual activity without any commitment while emerging adults would be expected to have developed an intimate relationship or commitment. Nevertheless, Papalia, Feldman, and Martorell (2012) stated that sociosexuality may peak in emerging adulthood because, in this period, people tend to more understand and be open to sexual activity. Nowadays emerging adults also find it difficult to fulfill their developmental tasks, such as planning the future or having financial resources because of the uncertainty of social and economic condition. Therefore, some emerging adults can tend to delay having a long-term commitment as they prefer to engage in a short-term relationship (Shulman \& Connolly, 2013).

In emerging adulthood, people begin to have their freedom and parental surveillance lessens (Arnett, 2000), particularly in the sexual term. The role of parents is crucial in the formation of children's personality because parents are the primary source for children in performing certain things, including those related to sexual behavior (Musthofa \& Winarti, 2010). Parents are also regarded as the most appropriate source to educate their children about sex (Levesque, 2003). Nevertheless, parents in Indonesia still worry that their children will be involved in sexual activity before marriage, either with the child's partner or with strangers. In Indonesia, having sex with someone other than marriage partner, either an affair or pre-marital sex, is perceived as bad or a negative thing. Sex before marriage is still perceived as a taboo in Indonesia because it is not suitable with the norms.

Consequences of having sex frequently with different partners, such as infection by HIV/AIDS, pregnancy, is one of the reasons why Indonesian parents worry about their children's sexual activity. Even though parents in Indonesia worry about their children's sexual activity, Fauzi (2016) found that they felt it was 'taboo' to educate their children about sex. Therefore, there are still many parents reluctant to talk about sex.

Finley, Mira, and Schwartz (2008) found that generally, a mother is more involved in children's lives than father. However, father involvement is as important as a mother for children's development. In addition, father involvement can also help the 
mother in nurturance. Culp, Schadle, Robinson, and Culp (2000) found that mother reported lower children's externalizing behavior if the father was involved. Moreover, the mother will have more positive perceptions about their children when the father is highly involved in child's life (Culp, Schadle, Robinson, \& Culp, 2000). The positive perception of the mother can help to develop a better relationship with the child.

In Indonesia, Munti (2005) stated that father's surveillance of child sexual behavior is considered as lower than mother's. On the other hand, Hepburn (1981, in Hutchinson, 2002) found that fathers have an important role in discussing sexual and moral topics. Father also plays an important role in discussing with their daughter about sociosexuality. Hetherington and Martin (1979 in Allen \& Daly, 2007) revealed that father involvement is correlated with child's sexual gratification, both for son and daughter. Ostovich and Sabini (2004) also found that sex drive was positively correlated to sociosexuality.

Regarding sociosexuality, Belsky et al (year, in Schmitt, 2005) found that mother involvement or father involvement in childhood can affect their children's mating strategy in later life. Therefore, it can be assumed that father involvement is not only crucial in discussing sociosexuality but also important to help children control their sexual behavior or sex drive, even to control their sociosexuality.

Finley and Schwartz (2004) classified father involvement into two domains -- father nurturance (affective domain) and father involvement (behavioral domain). Father nurturance refers to the warmth and acceptance (Finley, Mira, \& Schwartz, 2008), while father involvement refers to the extent to which father participates in various aspects of their child's life (Finley, Mira, \& Schwartz, 2008).

Generally, uninvolved fathers can affect various aspects of child's development, such as cognitive, emotional, social, physical, sexual, even well-being (Allen \& Daly, 2007). Therefore, based on previous explanations, it can be assumed that fathers play an important role in child's life and their involvement can affect child development. Thus, this study predicts that there will be a negative relationship between father involvement and sociosexuality in emerging adults.

\section{Methods}

Respondents. The present study used two ways to collect data - printed questionnaire and online questionnaire. The convenience sampling method was used in this study. Respondents in the present study were 526 emerging adults (203 from printed questionnaire and 323 from online questionnaire). The respondents resided in Jakarta, Bogor, Depok, Tangerang, and Bekasi. They were recruited using convenience sampling. Most of the respondents $(72.4 \%)$ in this study were female. This study was dominated by emerging adults aged 21 years old $(\mathrm{M}=20,98, \mathrm{SD}=1.422)$ and the majority $(39.9 \%)$ of respondents lived in Jakarta. Respondents were asked to choose their father figure and more than half $(98.9 \%)$ of the respondents chose biological father as their father figure.

Research Design. The quantitative approach was applied in this study. Based on the strategy applied, the present study is a correlational study because it sought to find the correlation between variables.

\section{Instruments and Measurement.}

Nurturant Fathering Scale (NFS: Finley \& Schwartz, 2004). Based on affective domain, father involvement was assessed with the NFS. This instrument consists of 9 items with five-point Likert scale responses from 1 (never involved) to 5 (always involved). Higher scores indicate higher perceptions of father involvement based on affective domain NFS's internal reliability was found to be $\alpha=.915$ and this instrument was valid to measure father involvement in affective domain.

Reported Father Involvement Scale (FIS-R: Finley $\&$ Schwartz, 2004). Emerging adult's reports of their father involvement in behavior domain were measured with the FIS-R. The measure consists of 20 items and each item is rated on a five-point Likert scale. There are three subscales: Expressive, Instrumental, and Mentoring/Advising. Both of expressive and instrumental subscales consists of eight items, whereas mentoring/advising subscales consists of four items. Cronbach's alpha coefficient for this measure was found to be .934. Nurturant Fathering Scale and Reported Father Involvement Scale were adapted to Bahasa by Amani (2016).

Revised Sociosexual Orientation Inventory (SOI-R: Pendke \& Asendorpf, 2008). Sociosexual orientation or sociosexuality was measured using SOI-R adapted to Bahasa Indonesia by Pradhana (2015). The adaptation process the SOI-R, that previously had 9 items, required an additional item 
as there was a double-barreled item. This instrument used a five-point Likert scale ranging from 1 (never or disagree) to 5 (always or agree). SOI-R was composed of three components of sociosexuality: sociosexual behavior, sociosexual attitude, and sociosexual desire. Both of sociosexual behavior and sociosexual desire consists of three items, whereas sociosexual attitude consists of four items. One item of sociosexual attitude component (number seven) is unfavorable item because the content is 'taboo' or might be sensitive for some respondents. Therefore, the unfavorable item reduces the probability of biased response. Higher scores indicate a higher level of sociosexual orientation (unrestricted sociosexual orientation). Cronbach's alpha was found to be .86 and each item was found to be valid to measure sociosexual orientation. The examples of the items of all instruments are shown in Table 1 below.

Table 1.

The examples of items of the instruments.

\begin{tabular}{|c|c|c|c|}
\hline Instrument & $\begin{array}{l}\text { Component } \\
\text { / Sub-scale }\end{array}$ & $\begin{array}{l}\text { Item } \\
\text { Total }\end{array}$ & $\begin{array}{l}\text { Sample of } \\
\text { Items }\end{array}$ \\
\hline NFS & & 9 & $\begin{array}{l}\text { How much do } \\
\text { you think your } \\
\text { father enjoyed } \\
\text { being a father? }\end{array}$ \\
\hline \multirow[t]{3}{*}{ FIS-R } & Expressive & 8 & $\begin{array}{l}\text { Emotional } \\
\text { development }\end{array}$ \\
\hline & Instrumental & 8 & $\begin{array}{l}\text { Career } \\
\text { development }\end{array}$ \\
\hline & $\begin{array}{l}\text { Advising/ } \\
\text { Mentoring }\end{array}$ & 4 & $\begin{array}{l}\text { Intellectual } \\
\text { development }\end{array}$ \\
\hline \multirow[t]{3}{*}{ SOI-R } & Behavior & 3 & $\begin{array}{l}\text { With how } \\
\text { many different } \\
\text { partners have } \\
\text { you had sex } \\
\text { within the past } \\
12 \text { months? }\end{array}$ \\
\hline & Attitude & 4 & $\begin{array}{l}\text { Sex without } \\
\text { love is OK. }\end{array}$ \\
\hline & Desire & 3 & $\begin{array}{l}\text { In everyday } \\
\text { life, how often } \\
\text { do you have } \\
\text { spontaneous } \\
\text { fantasies about } \\
\text { having sex } \\
\text { with someone } \\
\text { you have just } \\
\text { met? }\end{array}$ \\
\hline
\end{tabular}

Procedure. In the process of data collecting, printed questionnaire and online questionnaires were given to the respondents that had signed informed consent. Before they signed the informed consent, each participant received the information about the purpose of the study. After they signed the informed consent, they were asked to complete the demographic data and give response to each question in the questionnaire.

\section{Results}

\section{Results.}

The data shows that $80 \%$ respondents reported high father involvement in affective domain and $88 \%$ reported high father involvement in behavioral domain. From sociosexuality, the data has shown that most of the respondents $(98.9 \%)$ reported low sociosexuality or having restricted sociosexual orientation. High and low of father involvement were explained by the scores obtained by the respondents.

The correlation between father involvement, both affective and behavioral domain, and sociosexuality were found to be significant as seen in Table 2 .

Table 2.

Correlation between father involvement (affective $\&$ behavioral domain) and sociosexuality

\begin{tabular}{|c|c|c|c|c|}
\hline \multirow[b]{3}{*}{ Sociosexuality } & \multicolumn{4}{|c|}{ Father Involvement } \\
\hline & \multicolumn{2}{|c|}{$\begin{array}{l}\text { Affective } \\
\text { Domain }\end{array}$} & \multicolumn{2}{|c|}{$\begin{array}{c}\text { Behavioral } \\
\text { Domain }\end{array}$} \\
\hline & $\begin{array}{c}\boldsymbol{r} \\
-0.175\end{array}$ & $\begin{array}{c}\boldsymbol{p} \\
<0.01\end{array}$ & $\begin{array}{c}\boldsymbol{r} \\
-0.245\end{array}$ & $\begin{array}{c}\boldsymbol{p} \\
<0.01\end{array}$ \\
\hline
\end{tabular}

As shown in table 2, there was significant negative correlation for father involvement, both affective and behavioral domain, and sociosexuality. That is, the higher the father involvement in their child's life, either affectively or behaviorally, the less their children have unrestricted sociosexual orientation. Further analysis of father involvement found that father involvement in behavioral domain is higher than father involvement in affective domain.

\section{Discussion \& Conclusion}

In support of the hypothesis, the results demonstrated that higher father's involvement in children life, both in affective and behavioral domain, was related to lower sociosexuality that children have, in other words, the lower the child wants to involve in sex without commitment. The results can complement the previous finding by Hetherington \& Martin (year, in Allen \& Daly, 2007) about the correlation between father involvement and the control of sexual gratification. They stated that children with higher father involvement were most likely to control their sex drive, both for boys and girls. Besides that, Ostovich and Sabini (2004) have found that sex drive is correlated with sociosexuality. Furthermore, this 
current study has found that there is a direct relationship between father involvement and sociosexuality.

From the further analysis, the findings also show that behavioral domain of father involvement has higher coefficient correlation than affective domain of father involvement with sociosexuality. Perhaps, and in line with Hepburn (year, in Allen \& Daly, 2007), the most important thing that father could do in children's sexual development aspect was discussion and surveillance. Moreover, Arnett (2000) stated that one thing that can encourage the exploration of sexual experience in emerging adulthood is a lack of surveillance from parents. Either discussion or surveillance is included to mentoring/advising subscale of father involvement in behavioral domain. It appears that discussion and surveillance can give children's knowledge about sex and can improve the control of the children's sex drive so the children will have low sociosexuality.

However, there are several limitations of this study. The first relates to the retrospective nature of the instrument that has been applied to emerging adulthood. Because of that, the answers given by the respondents may be derived from the respondent's memories that have been distorted or mixed with current experience. Second, the scale used in this study was five-point scale or odd scale, which includes 'neutral' word in the middle. It may allow the respondents to choose 'neutral' on items that are highly social desirable. High social desirability results in respondents giving a response that is not according to them but rather socially acceptable response.

Future research may continue to use online data gathering to increase anonymity or eliminate the neutral scale to minimize social desirability. In addition, for the future study variables such as gender, religiosity, or sex drive might be added as the moderator or mediator, thus we can see what might affect the correlation between father involvement and sociosexuality.

This study presents new findings, particularly in Indonesia. Based on the results, it can be concluded that there is significant negative relationship between father involvement, both of affective domain and behavioral domain, and sociosexuality. It shows that the higher father involvement in children's lives, the lower sociosexuality emerging adults report. Furthermore, in emerging adulthood, father involvement in behavioral domain was more correlated with sociosexuality than father involvement in affective domain.

\section{References}

Allen, S. M., \& Daly, K. J. (2007). The effects of father involvement: An updated research summary of the evidence. Centre for Families, Work \& Well-Being, University of Guelph.

Amani, N. Z. (2016). Keterlibatan ayah dan sanctification of parenting: Studi pada anak remaja dan ayah di Aceh (Skripsi Sarjana). Universitas Indonesia.

Arnett, J. J. (2000). Emerging adulthood: A theory of development from the late teens through the twenties. American Psychologist, 55(5), 469.

Culp, R. E., Schadle, S., Robinson, L., \& Culp, A. M. (2000). Relationships among paternal involvement and young children's perceived self-competence and behavioral problems. Journal of Child and Family Studies, 9(1), 27-38.

Fauzi, I. (2016). Orang tua jangan menganggap tabu pendidikan seks kepada anak. Metro Tv News. Dikutip dari
http://news.metrotvnews.com/read/2016/05/03/5228 66/orang-tua-jangan-menganggap-tabu-pendidikanseks-kepada

Finley, G. E., \& Schwartz, S. J. (2004). The father involvement and nurturant fathering scales: Retrospective measures for adolescent and adult children. Educational and Psychological Measurement, 64(1), 143-164.

Finley, G. E., Mira, S. D., \& Schwartz, S. J. (2008). Perceived paternal and maternal involvement: Factor structures, mean differences, and parental roles. Fathering, 6(1), 62.

Hall, N. M., \& Pichon, L. C. (2014). Gender roles, sociosexuality, and sexual behavior among US Black women. Health Psychology and Behavioral

Hutchinson, M. K. (2002). The influence of sexual risk communication between parents and daughters on sexual risk behaviors. Family Relations, 51(3), 238247.

Lestari, D. \& Dono, D. (2016). Polisi temukan sindikat prostitusi online di Jakarta Utara. Dikutip dari http://m.news.viva.co.id/news/read/865432-polisitemukan-sindikat-prostitusi-online-di-jakarta-utara

Levesque, R. J. R. (2003). Sexuality education: What adolescents' rights require. New York: Nova Science Publishers.

Munti, R. B. (2005). Demokrasi keintiman: Seksualitas di era global. Yogyakarta: LKiS.

Musthofa, S. B. \& Winarti, P. (2010). Faktor yang mempengaruhi perilaku seks pranikah pada mahasiswa di Pekalongan tahun 2009-2010. Jurnal Kesehatan Reproduksi, 1(1), 32-41.

Ostovich, J. M., \& Sabini, J. (2004). How are sociosexuality, sex drive, and lifetime number of sexual partners related. Personality and Social Psychology Bulletin, 30(10), 1255-1266.

Papalia, D. E., Feldman, R. D, \& Martorell, G. (2012). Experience human development (12th edition). New York: Mc-Graw Hill. Universitas Indonesia

Penke, L., \& Asendorpf, J. B. (2008). Beyond global sociosexual orientations: a more differentiated look at sociosexuality and its effects on courtship and romantic relationships. Journal of Personality and Social Psychology, 95(5), 1113.

Pradhana, G. D. (2015). Prediksi relationship contingency of self-worth dan sosioseksualitas terhadap desakan menikah pada individu dewasa 
muda. (Skripsi Sarjana). Diunduh dari database Universitas Indoensia.

Safiera, A. (2015). Duh! Pengakuan pria yang jadikan Tinder untuk Cari pasangan one night stand. Wolipop. Dikutip dari https://wolipop.detik.com/read/2015/01/16/161847/2 805699/852/duh-pengakuan-pria-yang-jadikantinder-untuk-cari-pasangan-one-night-stand

Schmitt, D. P. (2005). Sociosexuality from Argentina to Zimbabwe: A 48-nation study of sex, culture, and strategies of human mating. Behavioral and Brain Sciences, 28(02), 247-275.
Shulman, S., \& Connolly, J. (2013). The challenge of romantic relationships in emerging adulthood: Reconceptualization of the field. Emerging Adulthood, 1(1), 27-39.

Simpson, J. A. \& Gangestad, S. W. (1991). Individual differences in sociosexuality: evidence for convergent and discriminant validity. Journal of personality and social psychology, 60(6), 870.

Vrangalova, Z., \& Ong, A. D. (2014). Who benefits from casual sex? The moderating role of sociosexuality. Social Psychological and Personality Science, 5(8), 883-891. 